\title{
Japan disputes need for moratorium on whaling
}

\begin{abstract}
Tokyo
"Whale resources are increasing. Why give up?" With these words emblazoned on her side, the mother ship of Japan's whaling fleet, the Dai San Nisshin Maru, sailed into Tokyo port last week, marking an end to Japan's commercial whaling in the Antarctic Ocean. But if the Fishery Agency has its way, the Nisshin Maru will soon set sail again for southern waters to carry out 'scientific whaling' for research purposes.

The International Whaling Commission (IWC) in 1982 called for a moratorium on all commercial whaling for five years from 1986 to 1990 . Japan tried to side-step the ban by filing an objection to the commission's ruling but was confronted with a US threat to slash Japan's fishing quota in the US 200-mile exclusive economic zone. And in July last year, Japan withdrew its objection on the understanding that Japan's commercial whaling in Antarctic waters would end in 1987 and in Japanese coastal waters in March 1988.
\end{abstract}

The imposition of the moratorium has raised bitter feelings in Japan, and over the past months the Japanese media have given a whale-by-whale account of the Nisshin Maru's last commercial voyage. On 27 November, the crewmen cheered and broke open a cask of sake (rice wine) as the first minke whale was hauled aboard. The announcement on 14 March that the 1,94ist minke whale, Japan's quota limit, had been caught was greeted by the crew with a more mixed response; those engaged in cutting up the catch said with deep emotion that they might never take up the cutting knives again.

Resentment in Japan over the moratorium runs high, not because whale meat forms an important part of the diettoday it is a delicacy eaten only on rare occasions-but because many Japanese - feel that a traditional industry already on its last legs is being bludgeoned to death by Western environmentalists on emotional rather than scientific grounds. IWC estimates place the population of minke whales in the Antarctic Ocean at more than 300,000 ; whaling experts from the Fishery Agency say this population is ample to sustain growth even if Japan continues whaling at present levels.

The issue seems set to come to the boil again in June at the IWC's next annual meeting, when Japan will put forward a plan to catch 825 minke whales and 50 sperm whales in the Antarctic Ocean in 1987-88 for scientific research purposes. The research whaling, to be carried out by the Nisshin Maru and two catcher vessels, will be supported by a budget of Y350 million from the Ministry of Agriculture, Forestry and Fisheries.

A spokesman for the World Wildlife Fund has already condemned the Japanese move as a 'scam' because the proposed quota is close to half of Japan's 1986-87 commercial quota and the whale meat will be used for consumption after research.

Clearly Japan is hoping that its whaling industry will be able to limp on and amass enough scientific data to convince the IWC that the moratorium should be lifted when it comes up for review in 1990. But one Tokyo restaurant specializing in whale meat has set aside storage space in a freezer for 70 tonnes of whale meat-the equivalent of about 14 minke whales-enough to keep the restaurant in business for at least the next six years.

David Swinbanks

\section{Superconducting} ceramics (contd)

\section{Tokyo}

HARDLY a day goes by without a Japanese company announcing a 'breakthrough' in the industrial development of the new superconducting ceramics. Now it is the turn of NEC Corporation.

It is less than a month since NEC researchers reported at Nagoya that they had observed the Josephson effect in the new ceramics at $80 \mathrm{~K}$ (see Nature 326,432 ; 1987). But already they claim to have a functioning Josephson junction device. Measuring 1 by 1 by $10 \mathrm{~mm}$, the junction is composed of two layers of single-phase yttrium-barium-copper oxide. Both AC and DC Josephson effects have been observed in the device at temperatures ranging from 0 to $90 \mathrm{~K}$.

Ultimately, NEC hopes that such devices will be used to make a superfast computer that can operate at liquid nitrogen temperatures. But temperature is not the only problem besetting the development of Josephson junctions into computers. Nobody has succeeded in combining several such devices into a viable chip because of different instability effects in each junction.

Details of NEC's new device will be announced at the Material Research Society spring meeting to be held in the United States from 21 April. David Swinbanks

\section{Explicit AIDS campaign offends TV watchers in Australia}

\section{Sydney}

IN Australia, an AIDS (acquired immune deficiency syndrome) campaign with a touch of mediaeval horror to it is causing controversy. The centrepiece of the $A \$ 3$ million national campaign is a television advertisement featuring the Grim Reaper as the symbol of AIDS death. The advertisement is designed to shock and scare. A rotting corpse clad in rags, carrying a scythe, aims a bowling ball at a group of ordinary Australians set up as tenpins. They are knocked dead. A little girl clutching a doll and crying is knocked flying for a spare.

The message of the campaign is that it is not only intravenous drug-users and homosexuals who are at risk from AIDS and that the only way of avoiding such a fate is to engage in 'safe sex'.

There have been complaints that the advertisement gives children nightmares, and demands that it not be screened when they could be watching.

Criticisms of the campaign include the lack of clear information on how AIDS is actually transmitted, that it ignores the importance of a partner's sexual history over the previous five years, and the use of exaggerated figures such as the estimate that "there are already 50,000 suspected carriers of the AIDS virus in
Australia"; other estimates put the number at more like 3,000. So far, there have been 238 deaths from AIDS in Australia.

According to the Minister for Health, Dr Neal Blewett, the shock strategy of the advertisement was designed to capture people's attention in competition with the vast amount of information pouring out of the media daily, to emphasize the seriousness of the problem and to encourage people to make further inquiries for themselves. In this, it seems to have been successful. After the launch of the campaign, the number of calls received by Sydney's main AIDS clinic quadrupled.

The AIDS campaign is also causing problems for schools. In response to the AIDS campaign, one of the national current affairs programmes intended for schools prepared an edition explaining what it all meant. But the New South Wales Department of Education, which is still deciding how to handle the question of AIDS, decided on the day before the screening that students would need parental permission to be allowed to watch it. Because of the lack of time to inform parents and receive a reply, very few children in the state saw the programme.
Charles Morgan 